\title{
THEORETICAL AND METHODOLOGICAL ASPECTS OF CREATIVE ECONOMY DEVELOPMENT
}

\author{
Patlasov Oleg \\ Omsk Humanitarian Academy, Omsk, Russia \\ Zharov Yerzhan \\ Academy of Public Administration under the President of the Republic of Kazakhstan, \\ Astana, Kazakhstan
}

The work presents the review of the theoretical and methodological aspects of creative economy formation and development, in all the variations and peculiarities of its functioning. It is highlighted that the level of technological development has its significant impact on how soon a particular economy is able to transfer to the phase of its creative development. Different criteria are reviewed in this regard, using which it would be possible to determine the presence of creative phenomena in economy along with their impact on the state and dynamics of socioeconomic relations. The authors' analysis covers the reasons that are leading to formation and development of creative economy, its development factors are defined. Results of the authors' sociological survey concerning creativity are also presented. Pre-requisites of its further development in Russia are defined.

Keywords: creative economy; creative class; creative industries; creative product; creativity criteria.

\section{Introduction}

Modernization of the traditional industrial industries and of the services sector, organization of intellectual operations, changes in the consumption structure along with the creative ideas' generation and information technologies' deeper penetration in all the sectors and business operations - all have contributed to formation of the background and the basis for market's functioning under brand new conditions.

Formed as a result of economies' modernization, new intellectual products are based on individual and collective creations, skills and talents of the master level, thus becoming the leading assets of the governments, businesses of all sizes and sector and of the general public too.

Considering this, from our viewpoint, "creative economy" shall be understood as a contemporary type of economic management, the key development driver of which is the discovery of personal creative abilities, new knowledge-generating technologies, which can be materialized as innovative products, having equally high creative and commercial value.

At that, creative economy is based on intellectual labor, bringing income not only from the end product, but from trading its results and rights for intellectual property as opposed to production of more traditional factors (Gazeta, 2018).

Creative economy represents the basis for the development of such diversified industries as trading, education, handicraft, architecture, mass media, cinematography, fashion and many others (UNESCO, 2013). New directions in development of creative 


\section{THEORETIC-METHODOLOGICAL ASPECTS}

economy are emerging all the time. As of today, they include electronic books, digital radio and television, Internet production in all its variety, computer games, mobile sector, digital video etc.

Although the role of creative resources and technologies in transformations of the socioeconomic systems is quite evident, many related issues remain understudied. Insufficient attention, inter alia, is devoted to the institutional aspects of creative economy's development, problems and perspectives of business development in the course of creative economy formation. The place of creative economy within the more general system of contemporary economic relations remains to be not specified. Thus, the aim of this work includes reviewing the key aspects of creative economy development along with its role within the system of global economic relations overall.

\section{Theoretical concepts of creative economy development}

In the era of scientific-technological transformations, mass digitalization and the increasing role of intellectual property, creative industry represents one of the most significant economic sector and, to some extent, a social sector too.

The UNCTAD statistics clearly demonstrates the sustainable growth of creative economy products worldwide and their trading too. On average, the annual growth of creative products' export and import equals to $18 \%$, thus, it is exceeding the rate of creative services provision (UNCTADSTAT, 2016).

According to the data, announced at SPIEF-2018 during the panel session "Export potential of Russia's creative industries", the capitalization of creative industries worldwide equals to 2.3 bln USD. Moreover, this sector is currently creating more than $30 \mathrm{mln}$ workplaces. As experts state, the rapidly growing creative industries today become the major drivers of both developed and developing economies, thus directly affecting the processes of earnings' formation, creation of new workplaces and export income growth (Exportcenter, 2018).

Governments of many countries are forecasting and expecting such changes, thus more and more efforts are invested in developing creative economies, since all benefits of the latter can be easily applied when responding to contemporary challenges, such as reducing the unemployment level, fighting poverty and environmental degradation etc. Contemporary national strategies for creative industries' development are directly related to economies' development overall, to creation of truly innovative enterprises, raising population employment rates, formation of more effective public sector and so on. For this reason, the importance of creative economy development is increasingly often highlighted in Russia too.

Generally speaking, we can differentiate the following list of actions, already taken by the government in an effort to target the creative sector development: development of infrastructure for creative entrepreneurship formation; removing barriers to development of creative industries; increasing the volumes of internal investments in $\mathrm{R} \& \mathrm{D}$ and also increasing the efficiency of these R\&D projects; encouraging, promoting and supporting the creation of new manufacturing; development of own/national strategic technologies (Kontrimiene, 2018).

In today's conditions, all problems of the creative sector tend to have their immediate effect on the national economy's competitiveness since reduced role and share of the creative class (which is known to be the engine of all innovations) in both research operations and in 
business (including art business and design) will always eventually lead to the loss of already achieved market positions. From the viewpoint of the international trade asymmetry, when one country is lagging behind another in terms of creative sector development, this will eventually lead to the increased gap in economic development between these two countries. The peculiarity of such a structural dependence is that it is extremely hard to overcome it once the opportunity is missed, simply because the progress in creative technologies demonstrated a really high speed, and also because all new technologies can be reproduced only on the basis of the already achieved results. If a country does not have own technical and technological solutions, then it would be nearly impossible for this country to create something truly new and original and thus make one more step in its development. For this very reason, the state of creative sector in a country and the state of its infrastructure in the first place are supposed to assure sufficient support and effective functioning of all creative processes. And they, in turn, become the defining factor in development of the whole society. Delivery of creative goods and services through import can partially solve the related problems but only for some time, and considering that updates and new releases in this sector are coming in nearly every day, even permanent import of creative products cannot become the basis for creation of a truly resilient competitive position of a country (Patlasov, Zharov, 2016).

Significant impact on the quickness of transfer to the stage of creative development also have the structure of the creative sector and the character of its functioning. If the economy is still based on traditional industries, mainly, on raw materials' extraction, then it would be rather difficult to develop the creative sector in this country as quickly as today's economy requires. In the countries with well developed services sector and wide spread of information technologies, the objective capabilities for creativity are usually higher and significantly. This can be explained by the fact that to form creative economy it is necessary to reach and maintain a certain volume of resources in the form of highly qualified specialists, information databases and communications, scientific knowledge base etc. Countries with significant share of the servicing sector, information economy, knowledge economy are usually in the center of all newest trends since they quicker adapt themselves to the constantly changing conditions of creative economy. Let's take Japan as a good example in this regard: production and manufacturing in this country are not so much materialconsuming, while the rate of human resources' development is rather high, and the latter is actually the major prerequisite for the national creative sector development (Patlasov, Zharov, 2017).

On the other hand, in Russian Federation the share of oil, gas and other raw materials in national export equals to over $75 \%$. This means that Russia's transmission to the stage of creative development would be for sure accompanied by a wide range of various complications, related to the objective reasons of structural character.

In today's conditions, companies and enterprises of the creative sector are often coming to the top level and becoming the points of growth, providing local and regional economies with new and updated intellectual and creative resources. Throughout the previous century the main drivers of most economies worldwide were large oil \& gas, metallurgic, car building and trading enterprises, while today the largest and the most recognizable worldwide companies are those from the creative sector (to name only a few, see Tab. 1). 


\section{THEORETIC-METHODOLOGICAL ASPECTS}

Table 1 - Rating of the most expensive companies, as of 2018 (Sourse: SharkFX)

\begin{tabular}{|l|l|l|c|c|}
\hline № & \multicolumn{1}{|c|}{ Company } & \multicolumn{1}{|c|}{ Area of operations } & $\begin{array}{c}\text { Value of } \\
\text { brand, bln } \\
\text { USD }\end{array}$ & $\begin{array}{c}\text { Market } \\
\text { capitalization, } \\
\text { bln USD }\end{array}$ \\
\hline 1 & Apple & Information technologies and electronics & 170 & 1,0 \\
\hline 2 & $\begin{array}{l}\text { Alphabet Inc. } \\
\text { Google })\end{array}$ & Internet services, applications, video-hosting & 101,8 & 857,3 \\
\hline 3 & Microsoft & Software & 87 & 833,98 \\
\hline 4 & Facebook & Social network & 73,5 & 507,2 \\
\hline 5 & Coca-Cola & Manufacturing of non-alcoholic drinks & 56,4 & 194,6 \\
\hline 6 & Amazon & Retail business in the Internet & 54,3 & 938,9 \\
\hline 7 & Samsung & Mobile devices, household appliances, PC & 38,2 & 304 \\
\hline 8 & Disney & Entertainment industry & 43,9 & 167,7 \\
\hline 9 & McDonald's & Catering & 40,3 & 124,2 \\
\hline 10 & Toyota & Car manufacturing & 41,1 & 198,1 \\
\hline
\end{tabular}

This increasing impact of the creative industries on the contemporary socioeconomic systems globalwide has found its theoretical grounding in the theoretical concepts of the post-industrial/information/knowledge society. Serious changes in manufacturing processes, re-orientation of production on creative goods mostly and also on the provision of creative services along with the ongoing processes of economic globalization are highlighted by the postindustrial theorists as the most fundamental features of this new type of society (Kloudova, 2010).

\section{Methodological aspects of creative economy analysis}

To measure the rate of the creative economies' development the OECD countries have developed their system of indicators, with the following directions: investments in scientific research and developments; the number of issued patents for inventions; expenses on education and retraining; creation of new workplaces in sciences and the sphere of high technologies; international cooperation in sciences and innovations; mobility of scientists, engineers and students; dynamics of the Internet distribution and coverage; the share of creative class in the society overall and the percentage of adult population with secondary and tertiary specialized education; the volume of population residing in the largest cities of the region.

In general terms, it is possible to differentiate four criteria which can be useful for creative economy analysis. These criteria are, in this or that way, offered by various researchers representing different countries: the criterion, related to operations; spatial criterion; technological one; and finally, industrial one. In parallel, we can also differentiate complementary criteria to all four of the above.

Criterion, related to operations.

This approach is closely related to the works of R. Florida, who paid a lot of attention to the input generated by talented people, their creative thinking and their ability to generate unique, out-of-box ideas. Transformations of socioeconomic relations usually happen when there is a sufficient number of people involved in operations within the creative sector. When 
we observe, in parallel, the reduction in the number of people involved in traditional productions and the increasing number of people working in the creative sector, we can interpret this trend as transfer to the stage of creative economy.

The labor concept of R. Florida has been based on the definition of creative class, consisting of two sub-classes: super-creative core and creative professions. The core of creative class consists of the people, directly involved in scientific and educational processes and operations, such as those in technical sphere, architecture, design, arts and entertainment industry. The key economic function of all these people includes the creation of brand new ideas, new technologies and new creative content. Apart from this core, the creative class includes a huge group of other creative professions. These people are working in business and finance, law, healthcare and some other adjacent fields (Florida, 2006).

Statistic observations demonstrate an increase in the share of people, directly or indirectly involved in the creative sector operations (in Western Europe, USA and Japan this share is already reaching $30 \%$ and goes further). In this decade already the creative class will become the major pushing force of economic growth for many countries globalwide. This new class will grow sharply and expand, gradually getting the largest share of all workplaces (Patlasov, Zharov, 2016).

The major problem with this approach is related to the complexity of the creative class identification. There are already quite many discussions on the issue of who is related to creative class, what labor can be classified as creative and how (why) does a certain level of income becomes the basis for segregation of creative class.

\section{Technological criterion.}

The background for this criterion is formed by the number of technological innovations, primarily in the field of information and communication technologies, which have already become available for a wide range of users worldwide. New technologies are usually the most noticeable signs of radical changes in the economic system overall, and for this very reason they often are named the drivers of economic development (Fuchs, 2008).

Simultaneously, a question arises about how is it possible to measure the development level of creative economy, using this technological criterion only. First of all, it would be rather difficult to trace how profound is a certain technology due to their large number and especially due to their permanent transformation. Secondly, there is no reliable measurement scale or method. In other words, it would nearly impossible to detect what is that point on a technological scale, reaching which an economy can be called creative. This complicated issue is avoided by many contemporary researchers who are limiting their studies only to some sort of general description of technological innovations, considering that this would be sufficient for the description of this brand new type of economy.

There is also another issue with this quantitative-only measurement of the technological criteria when defining how creative a certain economy is: for example, shall we consider that the economy of India, at least according to the number of submitted patent requisitions for inventions, is thus more creative than the economies of Australia, Great Britain and Canada?

Obviously, technological factor taken alone cannot be considered as the defining one when it comes to changing socioeconomic relations and formation of creative economy and creative social class in a certain country. 


\section{THEORETIC-METHODOLOGICAL ASPECTS}

Still, many researchers concentrate on these and other quantitative characteristics of development and insist that creative economy becomes a dominating trend in a particular country only at the point when certain quantitative thresholds have been reached (Irawan, 2014).

Table 2 - The number of patented applications for inventions, submitted by residents and non-residents to national patent authorities

(Source: WIPO; Ministry of Education and Science of the Russian Federation)

\begin{tabular}{|l|c|c|c|c|c|}
\hline \multicolumn{1}{|c|}{ Country } & 2000 & 2005 & 2010 & 2015 & 2016 \\
\hline Russia & 28688 & 32254 & 42500 & 45517 & 41587 \\
\hline Australia & 22001 & 23857 & 24887 & 28605 & 28394 \\
\hline Great Britain & 32747 & 27988 & 27988 & 22801 & 22059 \\
\hline Germany & 62142 & 60222 & 59245 & 66893 & 67899 \\
\hline Canada & 39622 & 39888 & 35449 & 36964 & 34745 \\
\hline Republic of Korea & 102010 & 160921 & 170101 & 213694 & 208830 \\
\hline USA & 295895 & 390733 & 490226 & 589410 & 605571 \\
\hline China & 51906 & 173327 & 391177 & 1101864 & 1338503 \\
\hline Japan & 419543 & 427078 & 344598 & 318721 & 318381 \\
\hline India & 8538 & 24382 & 39762 & 45658 & 45057 \\
\hline Vietnam & 1239 & 1947 & 3582 & 5033 & 5228 \\
\hline Malaysia & 6227 & 6286 & 6383 & 7727 & 7236 \\
\hline Thailand & 5049 & 6340 & 1937 & 7930 & n.d. \\
\hline
\end{tabular}

\section{Industrial criterion.}

Grounding for this criterion of the creative economy status was initially suggested by J. Hopkins, who had reviewed the model of creative economy, consisting of 15 sectors: advertisement, architecture, decorative art, handicraft, design, fashion, cinema, music, performance art, publishing business, $\mathrm{R} \& \mathrm{D}$, software, toys, television and radio, video games. Indeed, for all these industries, included into the classification, the top priority role belongs to the authorship rights, trademarks, brands, patents and the like (Hopkins, 2011). This approach to understanding the essence of creative industries has been followed and is now actively used by the World Intellectual Property Organization (www.wipo.int).

One of the interpretations for this industrial concepts is provided in the concentric model of D. Trosby. The core of this model is formed by the arts in the traditional understanding: music, ballet, theater, visual arts, handicrafts, literature. The following groups can be presented as expanding in concentric circles; here belong the industries that are manufacturing both artistic and non-artistic goods and services in parallel to each other, for example, books publishing, journalism, movie, television, radio and so on. Further from the core are located the industries which are functioning beyond the cultural field, but still include cultural content. This group includes advertising business, tourism and architectural services etc. (Throsby, 2008).

A system for evaluation of export and import volumes in creative industries has been developed by the UNCTAD. The key aim of its development has been to evaluate the depth of various countries' inclusion into the world creative economy. However, this does not automatically mean that the data provided for measuring these indicators is always accurate. This is related to the fact that data processing methods in different countries, quality and 
scope of the data these countries provide might be insufficient for full-scale analysis and calculation of the final indicators.

The existing today industrial concepts demonstrate very different ways of interpretation for structural parameters of the creative industries. Approaches to construction of such statistically measurable classifications are important because they enable more precise evaluations for the levels of creative economies' development.

\section{Spatial criterion.}

Understanding of creative economy essence should not be limited to separate sectors and research frames only, it may also have spatial interpretation - in the form of creative cities, creative clusters, creative capitals etc. Among other things, in accordance with the vision of C. Landry, cultural resources will become raw materials in the near future already, they will also turn into the basic assets of any more or less large city. Thus, cultural resources will also become the necessary precondition for the development of cities as creative spaces within innovative ecosystems. Creative city, according to Landry, is always formed by: a) innovative enterprises; b) effective cooperation between universities and entrepreneurship; c) developed infrastructure; d) opportunities for human leisure and self-development; e) welldeveloped mechanisms of social support (Landry, 2006).

One of the methods of how to transform a certain territory into "creative space" is through creative clusters and their inclusion in regional/local economic activities. Today in many countries such creative cluster are being formed and reformed on the basis of various industrial territories. Creative clusters thus become closely interconnected societies of creation-oriented entrepreneurs, who are interacting with each other on a very limited territory (Harvey, Hawkins, Thomas, 2012).

At that, stimulating creative clusters' development shall be seen not only as a means of urban space modernization, but also as an additional stimulating factor of creative industries' development.

In addition to theoretical research on spatial creativity, at the moment there are also methods being actively developed these days that would eventually enable the measuring of regions, countries, cities and other populated areas in terms of their creativity. However, any of the indicators offered in this regard bring in a lot of disputes, because the available, as of today, data is not always sufficient and/or revealing what we really need to know.

Additionally, at the moment there are many discussions still going on concerning a number of more general issues, such as what actually is a "creative city", for example? How can we differentiate between different levels of the creative cities development? What criteria should be considered in this context? What is the threshold number of creative cities in a country which would mean this country's successful transfer to the stage of creative economy?

\section{Authors' own sociological research on creativity}

To evaluate the level of creative economy development in Russian Federation, the authors of this article have arranged an online sociological survey. For this, we have used the online platform Survey Monkey. The total number of our respondents was 212 people. Our sample consisted mostly of business representatives, university staff, government and municipal employees, representatives of various creative professions, university students etc. 


\section{THEORETIC-METHODOLOGICAL ASPECTS}

Below we present the selected fragments of our, directly related to the issues of creative industries' development in Russia.

The survey respondents were asked to state what are, in their opinion, the most significant economic and social advantages, which may appear in the course of creative economy development in Russia (see Fig. 1).

According to the respondents' opinions, creative economy development will enable the creation of new workplaces $(67,3 \%)$, development of innovative processes in other economic sectors $(51,2 \%)$, creation of new capabilities and extra opportunities for businesses $(42,6 \%)$, economic diversification $(44,5 \%)$, increase in life standards $(34,1 \%)$, growth of export volumes and incomes $(24,6 \%)$, raise in labor output $(24,6 \%)$, more resource-saving $(17,5 \%)$, expansion of taxation base $(12,3 \%)$.

Further, the respondents were asked to name specific actions and mechanisms, which could expedite the process of transferring Russian economy to the stage of creative development.

Tab. 3 demonstrates the response options and the results we got (the respondents had the option of indicating more than three answers).

\section{Question: What economics and social benefits can appear due to development of creative economy in Russia (select not more than three options)?}
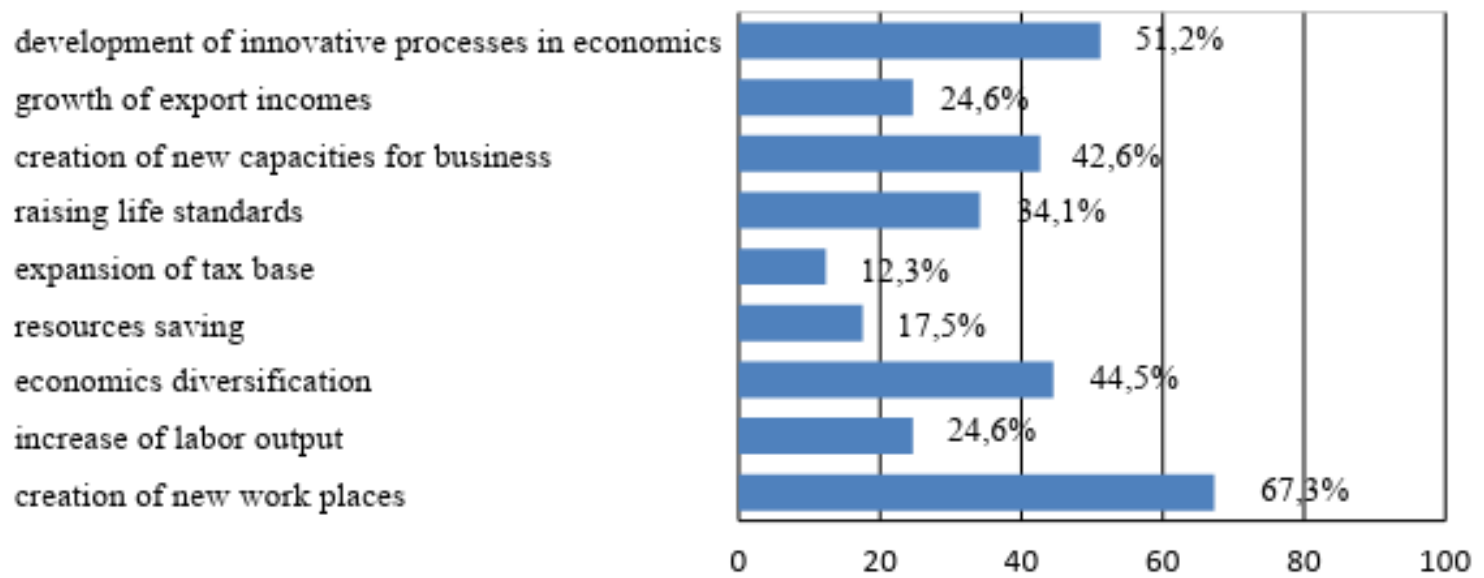

Figure 1 - Socioeconomic effects from creative economy development in Russian Federation, in $\%$ from all submitted answers (calculated and constructed by the authors) 
Table 3 - Actions, enabling the development of creative economy in Russia (respondents' answers, calculated and presented by the authors)

\begin{tabular}{|l|l|c|}
\hline$\#$ & \multicolumn{1}{|c|}{ Response options } & $\begin{array}{c}\text { Percentage, } \\
\text { in } \%\end{array}$ \\
\hline 1 & Preferential loans and tax preferences for the enterprises of creative sector & 66,9 \\
\hline 2 & Comfortable accommodation conditions for the creative class representatives & 25,4 \\
\hline 3 & $\begin{array}{l}\text { Reinforcing the legislation basis, particularly, launching and supporting } \\
\text { governmental programs for creative economy development }\end{array}$ & 47,8 \\
\hline 4 & Founding and supporting the functioning of creative clusters & 52,1 \\
\hline 5 & $\begin{array}{l}\text { Providing sufficient creative space for creative entrepreneurs, e.g., provision of sites } \\
\text { with low rental rates }\end{array}$ & 46,8 \\
\hline 6 & Strengthening the sociocultural potential of the local general population & 27,7 \\
\hline
\end{tabular}

One of the mandatory conditions for sustainable development of creative economy, as many respondents have stated, is governmental provision of preferential loans and tax preferences for the enterprises from the creative sector. Other important factors include: founding the creative clusters and their further development; reinforcement of institutional and legislative basis in this sector; and also, making sure there is sufficient creative space for entrepreneurs, more specifically - attention should be paid to the provision of business sites for renting out under low preferential rates (within business incubators, for example).

\section{Conclusions}

Creative economy has already become one of the drivers in the development of world economy and also in the progress of both developed and developing nations. Moreover, we have reasons to believe that today creative sector is gradually replacing traditional industries and even agriculture Strategic development plans of many already developed countries are now targeting creation and maintenance of sufficient and comfortable conditions for people's creative potential development which, in turn, would be supporting the development of creative industries and protection of people's intellectual property rights at the same time.

Significant role in this context belongs to the development of education institutions of various levels since the latter are expected to provide society with human resources capable of non-standard, creative thinking. For this very reason we can already observe a certain shift in education processes away from rather traditional means and methods. Education today should become more professional and "business-like", this also concerns the professions which previously were seen to be rather distanced from "doing business". Also, special place in the process of education/teaching should belong to the development of individual creative thinking, independent search for innovations and the like.

When it comes to academic research of creative economy development, more attention should surely be paid to the analysis of risks, current and potential, that are already hindering the development of full-scale creative economy. There are indeed countries and regions that are actively developing creative industries, at the same time, there are also regions, separated from these global tendencies of creative production and manufacturing, these regions are not using all the advantages that may enable the shift to a brand new type of economic system functioning. Differences between these two types of countries/regions (supporting the creative sector development and those neglecting it) include not only the level of their technological development, or the lack of investment resources available to them, or low 


\section{THEORETIC-METHODOLOGICAL ASPECTS}

level of human resources' development, but also the lack or underdevelopment of all related institutes.

Within the whole range of the prerequisites necessary for creative economy development in Russian Federation, there are several aspects which need to be distinguished separately.

Firstly, Russian education system has high enough potential for training all sorts of specialists needed for creative economy. It is important because under the current conditions of creative economy new capabilities and new ideas' implementation become the most decisive factor. Thus, we need more specialists with the highest levels of qualifications, specialists that are able to think creatively and develop special, customized solutions per specific situations.

Secondly, special attention should be paid to the development of original organizational and technological solutions designed specifically for making infrastructure of the creative sector more effective.

Thirdly, the already existing potential for creative industries' development in Russia can create the synergy effect for the whole economy of the Russian Federation.

Fourthly, we surely need to take into account the presence and the prominent role of two megacities - Moscow and St. Petersburg. There is also a certain number of other huge cities (with millions of residents in each). All these cities already have quite developed innovative ecosystems which enable them concentrate creative enterprises, universities and research centers on the territories of these cities. Urban areas in this case themselves become an important factor attracting hundreds and thousands of (potentially) creative specialists to these supercities.

Fifthly, Russia proudly owns rich cultural heritage which itself represents a significant element, able to stimulate further intellectual and creative development of the whole country.

\section{Acknowledgement}

This article was prepared with the financial support of the Russian Foundation for Basic Research (\#18-414-550001).

\section{References:}

Exportcenter (2018). The SPIEF discussed the export potential of Russian creative industries. Available at: https://www.exportcenter.ru/press_center/news/na-pmef-obsudili-eksportnyypotentsial-rossiyskikh-kreativnykh-industriy

Fuchs,C. (2008). The implications of new information and communication technologies for sustainability. Environ Dev Sustain 10:291-309 DOI 10.1007/s10668-006-9065-0

Florida, R. (2005). Creative class: people who change the future. Moscow: Classics-XXI.

Gaseta (2018). Creative Russia: position for export. From: https://www.gazeta.ru/business/2018/06/01/11783041.shtml?updated

Harvey, D.; Hawkins, H.; Thomas N. (2012). Thinking creative clusters beyond the city: People, places and networks, Geoforum 3: 529-539

Hopkins, J. (2011). Creative Economy. How to turn ideas into money. Moscow: Classics XXI. 256 p.

Irawan T. (2014), ICT and economic development: comparing ASEAN member states. Int Econ Policy 11: 97-114. 
Kloudova, J. (2010). Expanse creative economy and its impact on the less developed regions. Journal of the New Economic Association, 5: 110-125.

Kontrimiene, V. (2016). Creative Industries in the Temporary Economy: Globalization Processes. Vieðasis Administravimas (Public Administration), 3-4 (51-52): 38-47

Landry, C. (2006). Creative City. Moscow: Publishing house "Classics-XXI".

Ministry of Education and Science of the Russian Federation (2017). Results of scientific research and development. From: http://www.csrs.ru/archive/stat_2017_efficiency/ efficiency_2017.pdf

Patlasov, Yu.;. Zharov, Ye. (2017). Premises and Environmental Background for the Transition to the Creative Development of Economics. International Journal of Ecological Economics and Statistics 3: 134-150.

Patlasov, Yu.;. Zharov, Ye. (2016). Conditions for the transition to the phase of creative development of the economies of Kazakhstan and Russia. Science of man: humanitarian research, 2 (24).

Patlasov, Yu.;. Zharov, Ye. (2016). Formation of the creative class in the new economic reality. Vestnik SibADI, 6 (52).

Sharkfx (2018). Top 10 Most Expensive Brands in the World in 2018. Available at: https://sharkfx.ru/top-10-samyx-dorogix-brendov-mira-v-tekuschem-godu

Throsby, D. (2008) The concentric circles model of the cultural industries. Cultural Trends, 3: 147164.

UNESCO (2013). Creative Economy Report: widening local development pathways. From: http://www.unesco.org/culture/pdf/creative-economy-report-2013.pdf

United Nation Conference on Trade and Development (2016) UNCTADSTAT Creative Economy. Available at: http://unctadstat.unctad.org/wds/ReportFolders/reportFolders.aspx? IF_ActivePath=P,10\&sCS_ChosenLang=en.

WIPO (2017). WIPO IP Facts and Figures 2017. Available at: http://www.wipo.int/edocs/pubdocs/en/wipo_pub_943_2017.pdf

Paper submitted

Paper accepted for publishing

Paper published online
16 June 2018

21 July 2018

30 November 2018 